\title{
DEFENSIVE STRATEGIES USED BY NURSES IN THE ESTRATÉGIA SAÚDE DA FAMÍLIA TO COPE WITH DISTRESS
}

\author{
Paula Hübner Freitas ${ }^{1}$, Carmem Lúcia Colomé Beck², Viviani Viero³, Marcelo Nunes da Silva Fernandes ${ }^{4}$ \\ Katiusci Lehnhard Machado ${ }^{5}$
}

${ }^{1}$ M.Sc. in Nursing, Graduate Nursing Program, Universidade Federal de Santa Maria (UFSM). Santa Maria, Rio Grande do Sul, Brazil.
E-mail: enf.paulahf@gmail.com
${ }^{2}$ Ph.D. in Nursing. Professor, Nursing Department, UFSM, Santa Maria, Rio Grande do Sul, Brazil. E-mail: carmembeck@gmail.com
${ }^{3}$ M.Sc. in Nursing, Graduate Nursing Program, UFSM. Santa Maria, Rio Grande do Sul, Brazil UFSM. Santa Maria, Rio Grande
do Sul, Brazil. E-mail: viviviero@hotmail.com
${ }^{4}$ M.Sc. in Nursing, Graduate Nursing Program, UFSM. Santa Maria, Rio Grande do Sul, Brazil. E-mail: marcelonsf@gmail.com
${ }^{5}$ Master's student, Graduate Nursing Program, UFSM. Santa Maria, Rio Grande do Sul, Brazil. E-mail: klehnhard@yahoo.com.br

ABSTRACT: This study's aim was to identify defensive strategies used by nurses working in the Estratégia Saúde da Família to cope with distress and keep working. This structured descriptive and exploratory study with a qualitative approach was conducted Estratégia Saúde da Família units in a city in the central region of the state of Rio Grande do Sul, Brazil. A total of 16 nurses participated. Semi-structured interviews were used to collect data and thematic analysis was adopted. The results show that the work organization, conditions and relations are essential for the emergence and intensity of defensive strategies used in the workers' routine. By using defensive strategies, workers can minimize damage to their health, however, there is a need to expand collective actions focused on occupational' health, especially among managers.

DESCRIPTORS: Community health nursing. Strategies. Family health strategy.

\section{ESTRATÉGIAS DEFENSIVAS DO ENFERMEIRO FRENTE AO SOFRIMENTO NA ESTRATÉGIA SAÚDE DA FAMÍLIA}

\begin{abstract}
RESUMO: Este estudo tem como objetivo identificar as estratégias defensivas que os enfermeiros da estratégia Saúde da Família utilizam frente ao sofrimento para conduzir o seu trabalho. Trata-se de um estudo exploratório-descritivo estruturado em uma abordagem qualitativa de pesquisa, realizado em Unidades da Estratégia Saúde da Família de um município da região central do Estado do Rio Grande do Sul. Participaram 16 enfermeiros. Utilizou-se de entrevista semiestruturada para coleta dos dados, e análise temática. Os resultados mostraram que a organização, as condições e as relações de trabalho assumem papéis fundamentais no que se refere à origem e intensidade das estratégias defensivas utilizadas no cotidiano desses trabalhadores. Ressalta-se que, a partir das estratégias defensivas, os trabalhadores podem minimizar os danos a sua saúde, destacando-se a necessidade de ampliar ações coletivas que visem à saúde do trabalhador, principalmente junto aos gestores.
\end{abstract}

DESCRITORES: Enfermagem em saúde comunitária. Estratégias. Estratégia saúde da família.

\section{ESTRATEGIAS DEFENSIVAS DEL ENFERMERO FRENTE AL SUFRIMIENTO EN LA ESTRATEGIA DE SALUD DE LA FAMÍLIA}

RESUMEN: El objetivo de este estudio es identificar las estrategias defensivas que las enfermeras de la Estrategia Saúde Família usan de frente al sufrimiento para llevar a cabo su labor. Se trata de un estudio descriptivo y exploratorio estructurado con un enfoque cualitativo, realizado en las Unidades de la Estrategia Saúde Família de un municipio de la región central del estado de Rio Grande do Sul. Participaron 16 enfermeras. Se utilizaron entrevistas semi-estructuradas para recolectar los datos y, análisis temático. Los resultados mostraron que la organización, las condiciones y las relaciones laborales asumen roles claves con relación al origen y la intensidad de las estrategias defensivas utilizadas en la vida cotidiana de los trabajadores. Cabe señalar que, a partir de las estrategias defensivas, los trabajadores pueden reducir al mínimo los daños a su salud, destacando la necesidad de ampliar las acciones colectivas que visen la salud del trabajador, especialmente junto a los gestores.

DESCRIPTORES: Enfermería en salud comunitária. Estrategias. Estrategia de salud familiar. 


\section{INTRODUCTION}

Each profession is submitted to a specific model of labor organization, which may facilitate the workers' mental and/or physical health, or not. Working conditions influence the workers' physical health, while issues related to work organization operates in the psych functioning. ${ }^{1}$ Hence, workers exposed to situations that lead to distress use defensive strategies that manifest through an individual's own behavior, as each individual responds in a particular way to each situation. ${ }^{2}$

The practice of nurses in the Family Health Strategy (Estratégia Saúde da Família - FHS) encompasses some elements that include: their desires; the subjectivity of the care provided to patients; their multiple needs; physical, psychological, social, and spiritual dimensions; pleasure and distress experiences; and defensive and mobilization strategies that interact with the work organization. ${ }^{3}$

In this context, we highlight that the National Policy of Primary Healthcare was approved in 2006 through Decree N. 648, consolidating the FHS as a fundamental model to reorganize primary healthcare (PHC). ${ }^{4}$ This law, however, is not sufficient to ensure changes in the working conditions in the field of health. A lack of proper physical structure to perform activities, low level of recognition, and high demand may cause distress among workers and interfere in their health. Thus, it is important that healthcare workers pay attention to their physical and mental health because the quality of their actions depends on it. ${ }^{3}$

Workers may keep working without becoming sick by following the rationale of suffering normality, which is characterized by an achievement that resulted from the creation of individual and collective defensive strategies used to respond to suffering. ${ }^{2}$ Normality, however, does not imply absence of suffering. ${ }^{2}$

Thus, defensive strategies play a paradoxical role. They are positive to the extent that they protect individuals from distress caused by situations at work that generate conflicts, keeping one's psychological balance and avoiding illness. On the other hand, these defenses become negative when they immobilize the individual. Over time, this form of protection may exhaust when not used to cope with suffering, increasing one's likelihood to become ill. ${ }^{1-2}$

Considering that challenging experiences are imposed in the daily routine of FHS, understanding that workers need to use defensive strategies to stay healthy, and taking into account that the health of workers in this field has been a growing concern in the Brazilian Public Health System (SUS), this study's objective was identify the defensive strategies used by nurses working in the FHS to cope with distress and keep working.

\section{METHOD}

This structured, exploratory and descriptive study with a qualitative approach was conducted in the FHS units in a city in the central region of Rio Grande do Sul, Brazil. This city has 16 FHS teams; three units have two teams and the team of one unit covers two units. Note that, according to Decree N. 2.355 from October $10^{\text {th }} 2013,{ }^{5}$ each FHS team is responsible for the care provided to a population of approximately 2,000 people.

The management in this city corresponds to Full Primary Healthcare and awaits new deliberations concerning Health Regions. The healthcare services in this city are distributed in Health Center, FHS units, Community Health Agents Strategies, Specialized and Complementary Services, Hospitals, Child and Adult Emergency Rooms, and Health Surveillance Services. It also has a Mobile Health Service (SAMU) and an Emergency Unit outsourced to the Associação Franciscana de Assistência a Saúde (SEFAS).

There is also Occupational Health Reference Center (Centro de Referência em Saúde do Trabalhador - CEREST), a service of regional scope with the primary objective to prevent occupational accidents and diseases. It is composed of a multidisciplinary team and is organized according to three core areas: education, surveillance and care and encompasses cities in the $4^{\text {th }}$ Health Region*.

All the nurses working in the FHS units in this city, 16 nurses, participated in the study. Inclusion criteria were: being a nurse hired by public exam and working in the FHS for more than six months (time considered sufficient for adaptation). Exclusion criteria were: nurses who were on leave for any reason during the period of data collection. The study was conducted between January and April 2013.

Semi-structured interviews were used to collect data. The interview script addressed sociodemographic variables, which were analyzed

Municipal Health Plan of Santa Maria, 2013-2016 [1 $1^{\text {st }}$ version] December 2012. 
using descriptive statistics, and contained guiding questions/statements (tell me what motivates you to work in a FHS unit; how do you feel toward your work?; tell me some facts of your working routine that make you feel good; tell me some facts of your working routine that do not make you feel good; tell me how you deal with facts that do not make you feel good).

The interviews were conducted according to the workers' availability, taking into account ethical precepts and the participants' privacy. The places where interviews were conducted included the health center, the university the researcher is affiliated with, and the workers' and the researcher's homes. The interviews were recorded with the participants' consent and took between 40 minutes and 1 hour and 40 minutes.

Thematic content analysis was adopted. It is composed of three stages: pre-analysis, exploration of material, and treatment and interpretation of data. ${ }^{6}$ For that purpose, the material was skimmed, similar reports were grouped, and then the full material was read again.

In order to ensure confidentiality of the participants' identities, the letter " $\mathrm{N}$ " was used to identify the respondents, which corresponds to nurse, followed by a number that corresponds to the order in which the interview was held. The studies by Jacques Christophe Dejours and those of authors working with the psychodynamics of work were used in the discussion of results to provide theoretical foundation.

Note that this study is inserted in the Work, Health, Education and Nursing Research Group in the Research Line of Work and Management in Nursing and Health and in the topic workers' psychological health/distress, Graduate Nursing Program at the Universidade Federal de Santa Maria (PPGENF-UFSM).

This study meets ethical standards of research involving human subjects. The Certificate for Ethical Assessment (CAEE) is N. 12251112.1.0000.5346, report N. 183.570, from 2013, in agreement with Resolution N. 466/2012 from the National Health Council .

\section{RESULTS}

The population under study is young, aged between 26 and 35 years old; 14 are women and most are single. They exclusively work for the FHS and are in the service from one to four years. When these workers talk about their working environment, they mainly report structural limitations that affect the work process and list among things that give them pleasure the fact they like the work they perform, support provided by the team, social responsibility, and the fact that they work with the community.

Thus, the work organization, its conditions and relations play an essential role in the emergence and intensity of defensive strategies that are used in the routine of these workers so they can "keep on" working without becoming physically or mentally ill.

In this sense, two thematic categories emerged: Individual defensive strategies and Collective defensive strategies, described as follows:

\section{Individual defensive strategies}

One of the tools used by workers in an attempt to minimize burnouts and distress accruing from the work organization is the decentralization of actions and self-government.

I can tell you that I work one day at a time, organizing myself, planning. For instance, I'm not giving childcare consultations yet. I don't like this situation but I don't like to do a sloppy job, so I have my limitations and I've learned to accept them a little better (N6).

The workers also reported the importance of initiatives, of leadership, of having autonomy to make decisions and implement problem solving strategies and to intermediate relationship within the staff during the work dynamics to avoid distress, taking care of pendent affairs as fast as possible. We try to solve it as soon as it happens. Right away, otherwise I'll keep thinking what I should have said. It's worse (N8).

Another way is to adapt to the work dynamics with whatever is available to minimize barriers to the development of activities, so that the work is not harmed or impeded, avoiding burnouts and distress. It often leads to a lack of motivation to innovate and engage in one's working environment.

I try to make do with the material I have. I can't demand things that are not available in my daily routine. If I start saying: 'if I had this or that I'd be able to do it better' because then I'll become frustrated. So, I have to try and solve problems with whatever I have at hand. It usually works (N1).

Even though they go to great lengths to adapt to working conditions, perform tasks aspiring positive results and a "clean conscience", these workers acknowledge their limitations and use them to prevent even greater distress, so they draw a line up to which they are able to overcome difficulties, 
as the following excerpt shows: [...] I do what is possible. I've learned during the time I've worked here that there are things that compete and other that do not. So I try to do everything I can and my conscience is clean, I'm aware I won't be able to do everything, not a chance. If we assume all the responsibility, you freak out, you go crazy, then you may even do something stupid, because things do not depend only on us (N8).

Another nurse refers to an attempt to alleviate distress through spirituality, by becoming spiritually stronger.

I believe spirituality is essential in the life of any human being. It was what sustained me, gave me stability in these moments. It was essential for me (N8).

The workers also trivialized or rationalized situations, or used denial and escape strategies. Trivialization is concretized through passivity, indifference, resignation to injustice and suffering. In the setting under study, it is as if the worker's body is numb to bear work overload, the demands from the community, the challenges of the interpersonal relationship among the staff members, and remaining factors that become natural in the working routine within FHS units.

The use of defensive strategies lead workers to experience a state of "paralysis", not showing any reaction to the limitations imposed by the work organization. This way, motivation to be proactive appears to be exhausted. The following excerpt exemplifies this issue:

There are two options: I stress myself or let it be. Lately, I let it be, because stressing myself has not been effective. So, I turn my back and do my job. They don't want to fix the lights, well, I'll do my best, that's the way it is (N10).

Usually when I go there [city management], I come back with no answers, so I become more upset than when I left, I've got to a point where I try not even go there (N5).

To cope with distress, these workers also use rationalization as a defense strategy. Rationalization is a mechanism we use to assign coherent explanations to a given attitude or feeling. They report that distress accruing from the work organization and its conditions is natural. It is something inherent to the profession and nurses are supposed to deal with it and adapt to the real working conditions.

I think that the education in Nursing gives us a little of it, you have to assume everything [...]. It bothers me, disrupts my job, but there's no use. There must be someone to do it, someone who assumes it and makes it work [...]. I guess you have to experience distress from work, because you've studied for such a long time for this. I mean, you've studied and then you don't want to deal with some nursing responsibility, so that's why I don't suffer much (N3).

The workers have to keep an ethical posture toward pressure at work, demands and disrespect on the part of some patients, one has to "keep calm", having in mind the bond established with the community.

[...] sometimes, people are not very patient to wait in the front and call us names [...]. I've counted 'till ten, took a really deep breath and was very polite to her [...]. So, there are situations in which we have to deal with things like this. For this reason, I tell you, we often end up absorbing all that in the moment (N4).

In many situations, workers perform their tasks without critically reflecting on the harm they do to their health. They use the "not thinking about it", they use denial as an individual defense strategy. Denial is used to avoid frustration, to stop feelings of helplessness, hopelessness and inefficiency.

I keep on [...]. I don't know, I guess it's a bit of selfdefense; I try not to think much. In fact, you postpone, but it's an escape valve, defense, but I try not to think much about it, but of course it's distressing (N2).

Another factor mentioned by the workers is a need to become "involved with something else", both at work and at home, to "forget" distress caused by their jobs, not elaborating on the situations that generate such distress. The essence of these reflections is expressed in the following: [...] it's that thing, you're feeling distressed, leave and forget. I make a point forgetting (N2); [...] If I have some problem, I find as much work as I can, but sometimes you just stay there, still, then you start ruminating [...] (N3).

They also starting using escape as a strategy, in a search to perform only activities that are inherent to their profession because it generates pleasure, a feeling of usefulness. Additionally, the workers use a strategy in which they monitor the minutes left for the work shift to end, count the days for the weekend or day off or vacation, or even consider changing jobs so they enjoy an immediate and shortlived sense of pleasure, but an efficacious way to change the focus.

They consciously seek this escape at moments of extreme suffering, when they need to willingly alienate themselves, because trying to solve the problem is not an efficacious alternative. Because if they face the fact they receive little support from the health network, such as a lack of opportunities to discuss, to be heard, or to elaborate on distress, this would generate even greater suffering. 
[...] Now, for instance, I'm going on vacation. So, if something happens or there's that VIP patient, who comes practically everyday, I think, thank God I'll be on vacation on Friday. Or if it's not my vacation time, we think: the weekend is coming, holiday is coming; it's more or less like this (N10).

For me the weekend is a mandatory resting time. [...] I count the hours until when I can like, really forget it here. It already gives me comfort (N3).

Whenever I can, I go to the secretary and I try to talk [...] we hear things that make us upset. You feel like working in another city, you feel like finding another profession, leave, but then you think, what if everyone does the same, who is going to stay? (N9).

\section{Collective defensive strategies}

In addition to individual strategies used to tolerate distress caused by a lack of pleasure at work, workers need to adopt collective strategies. To minimize problems concerning the physical organization of labor, the workers consider it almost natural to allocate private resources to do the job when physical conditions compromise its quality.

They do not use collective power to make lasting changes that would facilitate their tasks, which would change their work environment, would value them or bring them dignity. It is possible that these issues would reach the management and cause even greater distress, according to the following excerpts: [...] one day we ran out of water so I said no, we may stay here, we may work the hours but we're not going to do any procedures. I refuse to make a procedure without being able to wash my hands, and that was the way they [management] fixed it [...]. Now I try to see case-by-case. If I can fix a situation in my way, in a calm way, without stressing myself, the better, otherwise I do whatever is possible, but I avoid asking (N8).

With regard to interpersonal relationships intrinsic to the work dynamics, the workers use respect and dialogue to minimize relational conflicts within the team as expressed in the following: [...] our team is very united, the residents have already integrated into the team so well we feel they are really part of the team. Anything we have to solve, anything if I'm not here, the resident nurse takes care, the nutritionist resident is always willing. So we don't have much controversy, you know, one says one thing and the other does not deny it, not even after the person leaves the position you know, we say: 'no, that's not the way it was supposed to be, but let's solve it'. So we are pretty calm (N1).

Weekly meetings with the participation of all the staff members to discuss organizational problems and other meetings that may be scheduled during the work routine are also a strategy to preserve unity, to keep the group united, avoiding misunderstandings, misinformation or disrespect. For this reason, whatever the majority agrees on during meetings is strictly followed, as shown in the following: [...] I try to discuss everything in the meeting with the team. Sometimes, you see someone is upset, but everyone agrees, everything is discussed, talked through, everyone has a chance to choose, the team reaches a consensus, and we have to adapt (N8).

They also use dialog as a tool to solve problems both with regard to interpersonal relationships and Community Health Agents, so that problems are treated in a transparent way and do not become worse, which is a collective strategy and helps to alleviate suffering.

These moments are also opportunities for the team or a specific worker to share feelings of distress, so that it can be an individual defense strategy, as the worker feels "relieved" to keep working in the next shift or next days, as the following excerpts show: [...] that's what I do, I talk to my team, I talk to my technician, with our colleagues, with the residents, we talk a lot, so it's sort a therapy in which we talk about everything to solve each other's problems. That's how we do not take problems any further [...]. We sit down and solve everything before resuming work, something related to the team relationship, something that requires sitting and talking, as I said, so there's no chitchat going on (N1).

Another strategy used by the workers to cope with distress are times when they can relax, such as during group educational activities, commemorative parties, as well as leisure activities promoted out of the work environment with members of the team they have greater affinity with, which is clarified in the following: [...] I guess that these activities, for instance, a gymnastic group, a craftwork group, a group of gals, is really good, the girls also mentioned they unwind a lot in this group (N4); [...] we celebrate, Easter, we exchange chocolate, a party at the end of the year to close off activities. These parties help to alleviate stress, then you drink some juice or beer, it helps (N7).

Therefore, they seek the support of co-workers who are in the "same boat", but do not clarify why a strategy with the power to change what is causing distress, only minimize it, is used only among them; they dialogue among themselves or within the team, and this dialogue does not leave the group.

The use of some of the strategies aforementioned may be explained by the fact that the workers mentioned there are few opportunities to discuss, participate and talk to the management. The city 
does not have a Specialized Service in Safety Engineering and Occupational Medicine (SESMT), which is regulated by Standard N. 04, in order to promote the health and protect the integrity of municipal workers. ${ }^{7}$ It hinders the control and minimization of the impact labor generates in the health of municipal workers.

\section{[...] I realize that pain, for us, nurses, technicians,} those who integrate the team, even though there's occupational health in the city, we don't feel welcomed by it or connected to this service. It seems it is so distant from workers, so distant from us, it seems we're only able to access this service if we have some occupational accident, if we have an accident with a needle, or are cut by some contaminated material, because it seems really distant from the other services. Because, there is no cooperation between PHC and CEREST, which is a specialized reference service for occupational health in the city (E13).

This fact may contribute to trigger occupational diseases and some workers already experience manifestations in their health and others fear they may acquire occupational illnesses, both physical and mental disorders: [...] it's complicated, we keep going, for this reason I said that I've already went to a psychologist, because it's not easy (N16); [...] then I became sick, I got to this point last year, [...] I had pyelonephritis, otitis, pharyngitis, and then sinusitis (N8); $[. .$.$] we have to work with whatever we have and$ then the suffering, we don't know until when we'll be able to tolerate it, because the teams are new, they're working relatively well, are people who just started working and there's still a lot to do, but I don't know until when distress will go unnoticed by workers, because some day it'll surface (N9).

Therefore, these workers acknowledge that, because they have little time of service, they are able to avoid further damage to their physical and/ or psychological health but consider that, if they remain in this same rhythm and under the same work conditions, disorders may emerge.

\section{DISCUSSION}

Given the limitations and work organization, the workers from the FHS tend to use defensive strategies that enable them to deal with situations that cause distress, in an attempt to keep working without harming their performance and health. Thus, they use both individual and collective defensive strategies.

Because these workers have not worked in the FHS for a long time, some still have expectations with regard to the job and, when some of these ex- pectations are not met, they may experience distress and disease if defensive strategies are not adopted. ${ }^{8}$

At the same time, it is understandable that workers use little subjective mobilization, which is characterized by a movement of individuals that enables their ability to feel, think, and invent the work, and is relevant to re-signify suffering accruing from work. ${ }^{9-10}$ It is through subjective mobilization that workers are compelled to resist suffering and re-signify it towards pleasure.

A predominance of defense mechanism or defensive strategies is mainly intended to camouflage suffering, which explains the fact that workers present apparent normality, even though they are experiencing psychological distress. ${ }^{10}$ Over time, these workers may become rigid and resistant to changes to protect themselves from distress. ${ }^{11}$

Another factor that hinders elaboration of suffering among these workers is the distance they experience between the FHS unit, the managers and CEREST. Because the city provides few opportunities for discussion, participation and cooperation among workers, there are no actions to change the work organization, which often produces in workers a feeling of disconnection and isolation from the organization of their own work.

Managers play an essential role in the program implementation process and monitoring, as well as in providing proper conditions for workers to feel valued in their practice and for patients to have their rights ensured. It is the managers' role to guide the program supporting workers, so they feel motivated to implement the necessary improvements and innovations. ${ }^{12-13}$

Thus, a restricted dialogue and few collective decisions do not favor interpersonal relationship and the organization of work. Collective reflections and discussions about the way the work process is organized are relevant for the development of strategies and mobilization of workers. ${ }^{14}$

Therefore, a dialogue has to take place at all hierarchical levels in an equal relationship. Organizing a space of freedom implies that workers adapt their needs creatively, finding new sources of pleasure.

Hence, the importance of workers' expressing themselves, to "talk and be heard seems to be the most appropriate way to think, and therefore, to reflect upon one's own experience, as long as one is committed to a dialogical, inter-subjective relationship in which one believes the other is in fact trying to understand. It is when I explain to 
another my suffering, my relationship with work, that I, perplexed, hear myself say things I did not know until I said them". 15: 176

Therefore, there is a need to approximate CEREST and managers so that workers can implement new working processes, more coherent with the real context, that is, workers can use practical intelligence and creativity to establish collective opportunities to dialogue ${ }^{16-17}$ which can help them to cope with difficulties that arise in the context of work, to effectively transform suffering and avoid risks to their health, decreasing distances between the real and the prescribed work.

Additionally, political empowering of nurses, and understanding of the interdependence among the actors of the healthcare network (so that workers feel co-responsible for solving the issues that interfere in occupational health) is crucial to strengthen the healthcare network and collective actions.

Based on skilled management, connected with the remaining workers and including the community, creative and innovating decisions can be made to favor the collectivity, strengthening the occupational healthcare network and decreasing physical and psychological occupational illnesses.

\section{CONCLUSION}

Even though defensive strategies help to maintain psychological balance, they do not play a mobilizing role for the implementation of changes necessary in this context. Therefore, these workers are on the boundary between normality and pathology, probably because of the little time they work in the FHS.

This study identified the defensive strategies the nurses working in the FHS use to avoid suffering accruing from their context of work, which can support enlarged reflections and discussions in the academic milieu to minimize suffering among future workers in the context of their professional practice.

These notes should also broaden the scope of discussions in the field of public health policy and occupational health, readjusting territorial and population coverage, along with the planning and organization of the resources necessary in care delivery.

Strategies to effectively improve the work of professionals from the FHS should be sought in order to raise their quality of life and minimize factors that contribute to illnesses.

\section{REFERENCES}

1. Mendes AM. Psicodinâmica do trabalho: teoria, método e pesquisas. São Paulo (SP): Casa do Psicólogo; 2007.

2. Dejours C. A banalização da injustiça social. Rio de Janeiro: Editora FGV; 2006.

3. Siqueira GFF, Barrêto AJR, Menezes MS, Alves SRP, Freitas FFQ; Trabalho do enfermeiro na atenção primária em saúde: conhecimento dos fatores estressores. Rev Ciênc Saúde Nova Esperança. 2013; 11(2):72-85.

4. Ministério da Saúde (BR). Portaria no 648/GM de 28 de março de 2006: aprova a Política Nacional de Atenção Básica, estabelecendo a revisão de diretrizes e normas para a organização da atenção básica para o Programa Saúde da Família (PSF) e o Programa Agentes Comunitários de Saúde (PACS); 2006 [cited 2015 May 28]. Available from: http://bvsms.saude. gov.br/bvs/publicacoes/prtGM648_20060328.pdf

5. Ministério da Saúde (BR). Portaria n ${ }^{\circ} 2.355$, de 10 de outubro de 2013: Altera a fórmula de cálculo do teto máximo das Equipes de Saúde da Família. [cited 2015 Jun 03]. Available from: http:// bvsms.saude.gov.br/ bvs/saudelegis/gm/2013/prt2355_10_10_2013.html

6. Minayo MCS. O desafio do conhecimento: pesquisa qualitativa em saúde. $12^{\mathrm{a}}$ ed. São Paulo (SP): Hucitec; 2010.

7. Ministério do Trabalho (BR). Portaria MTPS n. ${ }^{\circ} 510$, de 29 de abril de 2016: NR-4, Serviço Especializado em Engenharia de Segurança e em Medicina do Trabalho. [cited 2015 Jun 08]. Available from: http:/ / www.mtps.gov.br/images/Documentos/SST/NR/ NR4.pdf

8. Anchieta VCC, Galinkin AL, Mendes AMB, Neiva ER. Work and risks of illness: a study among policemen. Teoria Pesqu. 2011; 27(2):199-208.

9. Ferreira JB. Análise clínica do trabalho e processo de subjetivação: um olhar da psicodinâmica do trabalho. In: Mendes AM, Merlo ARC, Morrone CF, Facas EP, organizodores. Psicodinâmica e clínica do trabalho: temas, interfaces e casos brasileiros. Curitiba (PR): Juruá Editora; 2010. p. 129-39.

10. Merlo ARC, Mendes AM, Moraes RD. O sujeito no trabalho: entre a saúde e a patologia. Curitiba (PR): Juruá Editora; 2012.

11. David HMSL, Mauro MYC, Silva VG, Pinheiro MAS, Silva FHS. Primary care nurse work organization: an occupational health issue. Texto Contexto Enferm. 2009; 18(2):206-14.

12. Molesini JA, Formigli VL, Guimarães MCL, Melo CMM. Programação pactuada integrada e gestão compartilhada do SUS. Rev Baiana Saúde Publica. 2010; 34(3):623-38.

13. Shimizu HE, Couto DT, Merchan-Hamann E. Psychosocial study about the consequences of work in hospital nurses as human resource management. Rev Latino-am Enfermagem. 2011; 21(Spe):61-70. 
14. Martins SR, Mendes AM. Espaço coletivo de discussão: a clínica psicodinâmica do trabalho como ação de resistência. Rev Psicol, Organ Trab. 2012; 12(2):171-84.

15. Dejours C. Conferências brasileiras: identidade, reconhecimento e transgressão no trabalho. São Paulo (SP): Fundap; 1999.
16. Dejours C. A loucura do trabalho: estudo de psicopatologia do trabalho. São Paulo (SP): CortezOboré; 1992.

17. Kessler AI, Krug SBF. Do prazer ao sofrimento no trabalho da enfermagem: o discurso dos trabalhadores. Rev Gaúcha Enferm. 2012; 33(1):49-55. 